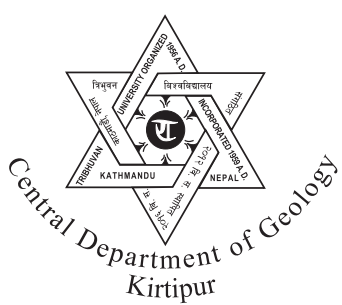

\title{
Basinal and planform characteristics of the Kodku and the Godavari Rivers, Kathmandu, Central Nepal
}

\author{
*Naresh Kazi Tamrakar and Ramita Bajracharya \\ Central Department of Geology, Tribhuvan University, Kirtipur, Kathmandu, Nepal
}

\begin{abstract}
The rivers of the Kathmandu Basin are vulnerable to flash floods and disturbances caused by anthropogenic as well as climatic changes. Two southern tributaries of the Bagmati River: the Kodku and the Godavari Rivers, have been considered for their (i) watershed-scale geomorphic parameters such as relative relief, drainage texture and stream order, (ii) stretchscale planform parameters such as sinuosity $(\mathrm{K})$, meander belt width $\left(\mathrm{W}_{\mathrm{blt}}\right)$, meander wavelength $\left(\mathrm{L}_{\mathrm{m}}\right)$ and radius of curvature $\left(\mathrm{R}_{\mathrm{c}}\right)$, and (ii) longitudinal profiles and slopes. Both Kodku and the Godavari Rivers are elongate basins with wide ranges of the watershed-scale parameters. The Godavari River is longer, larger and more sinuous compared to the Kodku River. The development of the patterns of the fifth order main stem stretches of both rivers with respect to the stream slopes, and asymmetric patterns of the meander loops indicate anomalous growth of the river stretches.
\end{abstract}

\section{INTRODUCTION}

Two major tributaries of the Bagmati River from the southeastern Bagmati Basin are the Kodku and the Godavari Rivers (Fig. 1). These rivers have a typical source of metasedimentary terrain composing dominantly of limestone of the Phulchoki Group (Stöcklin, 1980). Rivers flow slightly northwestward to contribute Bagmati River segments, i.e., the Hanumante River by the Godavari River and the Manahara River by the Kodku River. Both the Kodku and the Godavari Rivers are of fifth order with sinuous pattern. They have wide floodplains but narrow current meander belts.

Urbanization in both the Godavari and the Kodku Rivers is very rapid at the present moment. Many civil colonies have been erected and roads have been extended to facilitate transportation. In this circumstance of

*Corresponding author:

E-mail address: nktam555@gmail.com growing trend of urbanization, the rivers have been notably disturbed and instead the rivers have become threats to the settlement area, as they may unexpectedly flood and inundate the floodplains. There were many flash flooding taking place in the Kodku River. In 1979 Dhapakhel area was flooded, while in 1981, 2002 and 2007, Imadol and Gwarko areas were flooded and damaged partially. In 2002 Gwarko area was inundated for more than a week. Similarly, the Godavari River was flooded in 2006 and inundated and partially destroyed Balkot and Dharmeshwar areas. Therefore, there is no doubt that the rivers of the Kathmandu valley, including the Kodku and the Godavari Rivers bring about flash flooding and partly destroy and inundate the cultivated lands and settlement areas.

Understanding the watershed scale relief and river system and planforms are crucial in the study of the river hydrology and the river related hazards (Tamrakar, 2004; Shrestha and Tamrakar, 2007; Shrestha and Tamrakar, 2011). In light of this, the present study 


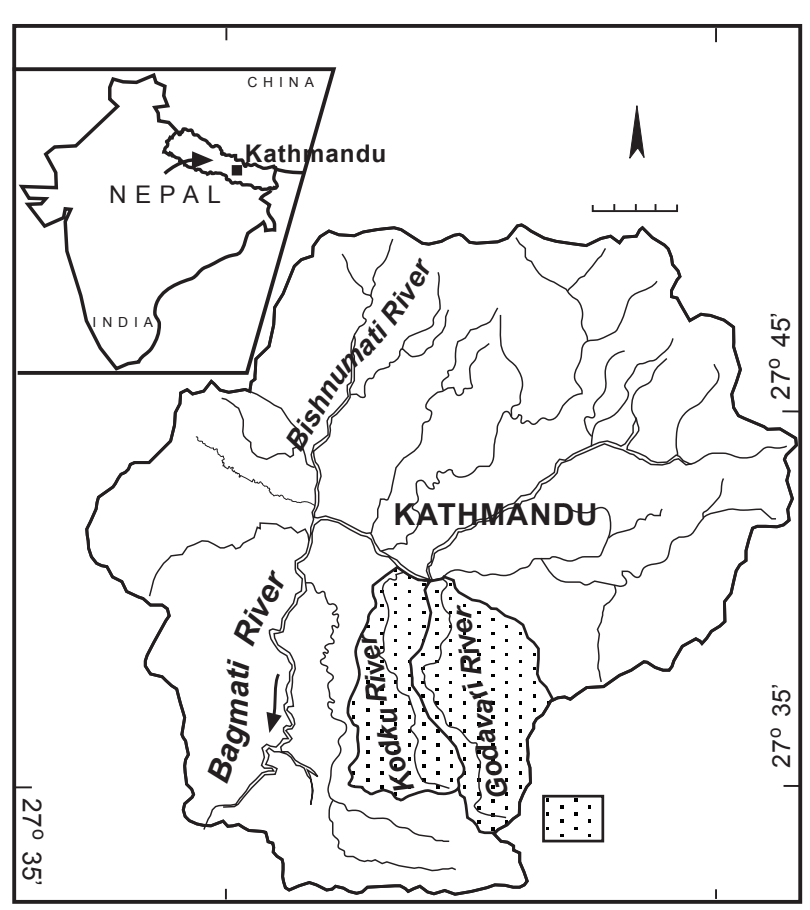

Fig. 1 Location of study area

focuses on generation of watershed scale parameters and river planform parameters for the two southern tributaries of the Bagmati River.

\section{WATERSHED-SCALE PARAMETERS OF THE KODKU RIVER}

Watershed-scale parameters incorporate relative relief, drainage texture and stream order for determination of which the spatial aspect of the whole watershed is considered.

\section{Relative relief}

Relative relief (RR), which is defined as the difference in height between the highest point and the lowest point on the grid of a square kilometer, can be categorized into six classes as shown in Fig. 2. RR ranges from extremely high to low. It is extremely high in Majhgau and Badikhel, high in Muldol area, and moderate to moderately low in Taukhel Dhapakhel, Harisidhi and Khumaltar. It is low in Imadol area. RR diminishes from the south to the north of the watershed.

\section{Drainage texture}

The drainage texture (DT) is defined as the number of stream segment passes across per unit length within the square grid area (Horton, 1945). According to drainage texture, basin can be classified as shown in Fig. 3, into six categories ranging from extremely coarse to very fine (Singh, 1981). DT ranges from fine to very coarse (Fig. 3). It is fine in the southern mountain area such as Badikhel, moderate in Majhgau and Muldol, coarse in Bulu and Khatrigau, and very coarse in Taukhel, Harisidhi, Khumaltar and Imadol. Areas with bedrocks and relatively high relief constitute relatively fine DT. DT is controlled by distribution of bedrocks and soft sediments.

\section{Stream order}

Stream ordering refers to the determination of the hierarchical position of a stream within a drainage basin. Stream order is defined as 'a measure of the position of a stream in the hierarchy of tributaries' (Leopold, Wolman and Miller, 1964). In this study, the drainage order was determined using the method proposed by

Table 1: River morphological data of the Kodku and the Godavari Rivers

\begin{tabular}{|l|c|c|c|c|c|c|}
\hline Parameter & \multicolumn{3}{|c|}{ Kodku River } & \multicolumn{3}{c|}{ Godavari River } \\
\hline & 5th & 4th & 3rd & 5th & 4th & 3rd \\
\hline Channel length (m) & 11995.2 & 446.25 & 3427.2 & 13280.4 & 2266.415 & 1511.71 \\
\hline Belt length (m) & 8996.4 & 339.15 & 3391.5 & 8192.27 & 1630.941 & 1445.99 \\
\hline Sinuosity & 1.33 & 1.315 & 1.01 & 1.62 & 1.38 & 1.05 \\
\hline Meander belt width (m) & 125.97 & 44.625 & 54.76 & 138.92 & 55.99 & 73.94 \\
\hline Meander wave length (m) & 248.80 & 142.8 & 226.34 & 301.80 & 287.74 & 209.61 \\
\hline Radius of curvature (m) & 65.56 & 60.018 & 55.89 & 90.15 & 110.89 & 103.93 \\
\hline Slope (m/m) & 0.46 & 1.309 & 3.58 & 0.83 & 5.16 & 13.60 \\
\hline Average slope & \multicolumn{7}{|c|}{2.58} & \multicolumn{3}{|c|}{4.18} \\
\hline
\end{tabular}

*Sinuosity (K): $\mathrm{S}=$ sinuous (1.05 to 1.5$) ; \mathrm{St}=$ straight $(<1.05)$ based on Leopold and Wolman (1957) 


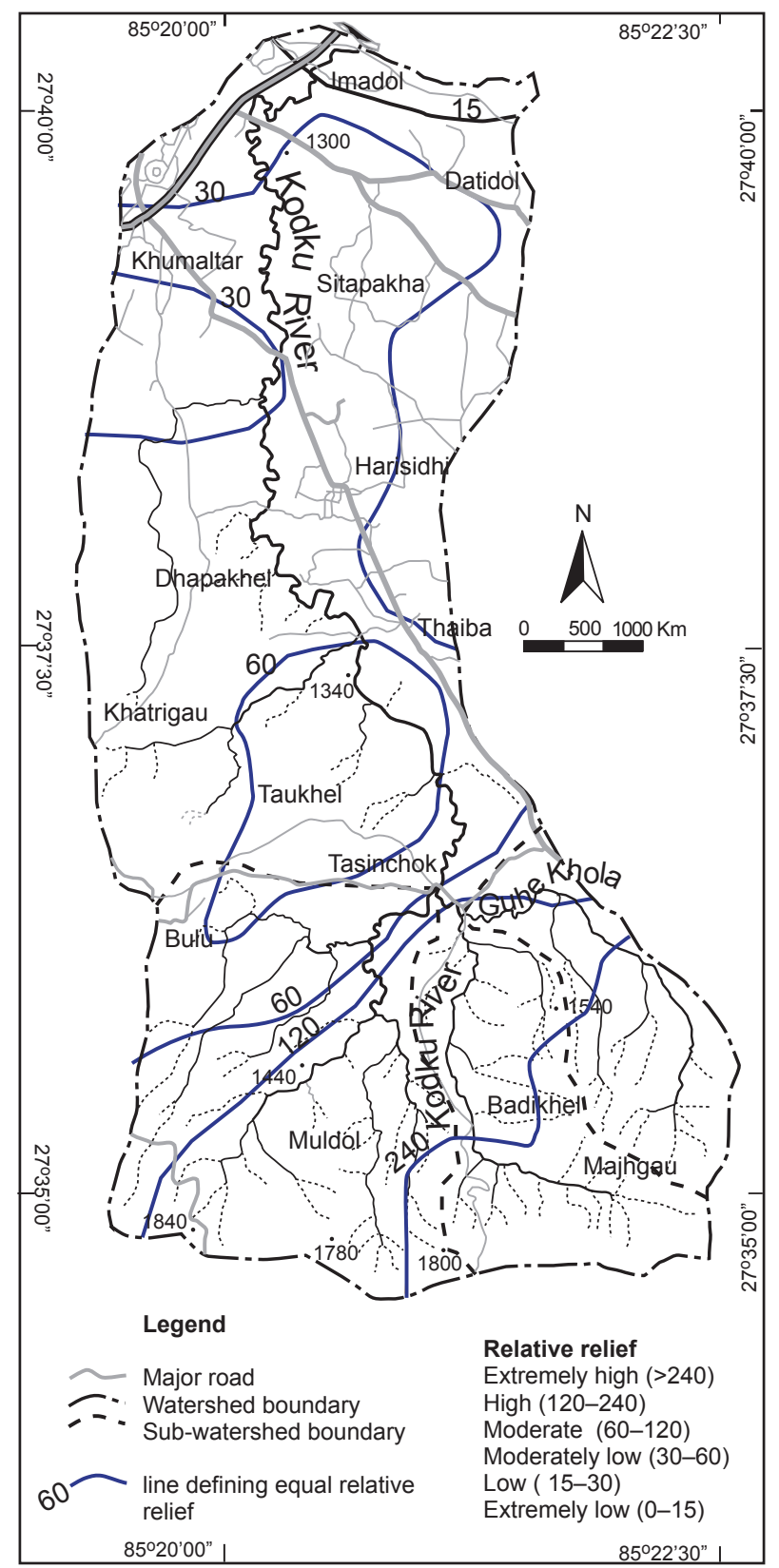

Fig. 2 A map showing relative relief in the Kodkhu watershed.

Strahler $(1957 ; 1969)$.

The Kodku Watershed constitutes three subwatersheds, of which the elongate Kodku sub-watershed is contributed by the Guhe sub-watershed from the east and the sub-watershed (Muldol area) from the southwest. The Kodku mainstem River is the fifth order river. There are altogether twenty-two 2nd order, six 3rd order and two 4 th order streams in the watershed. The third order

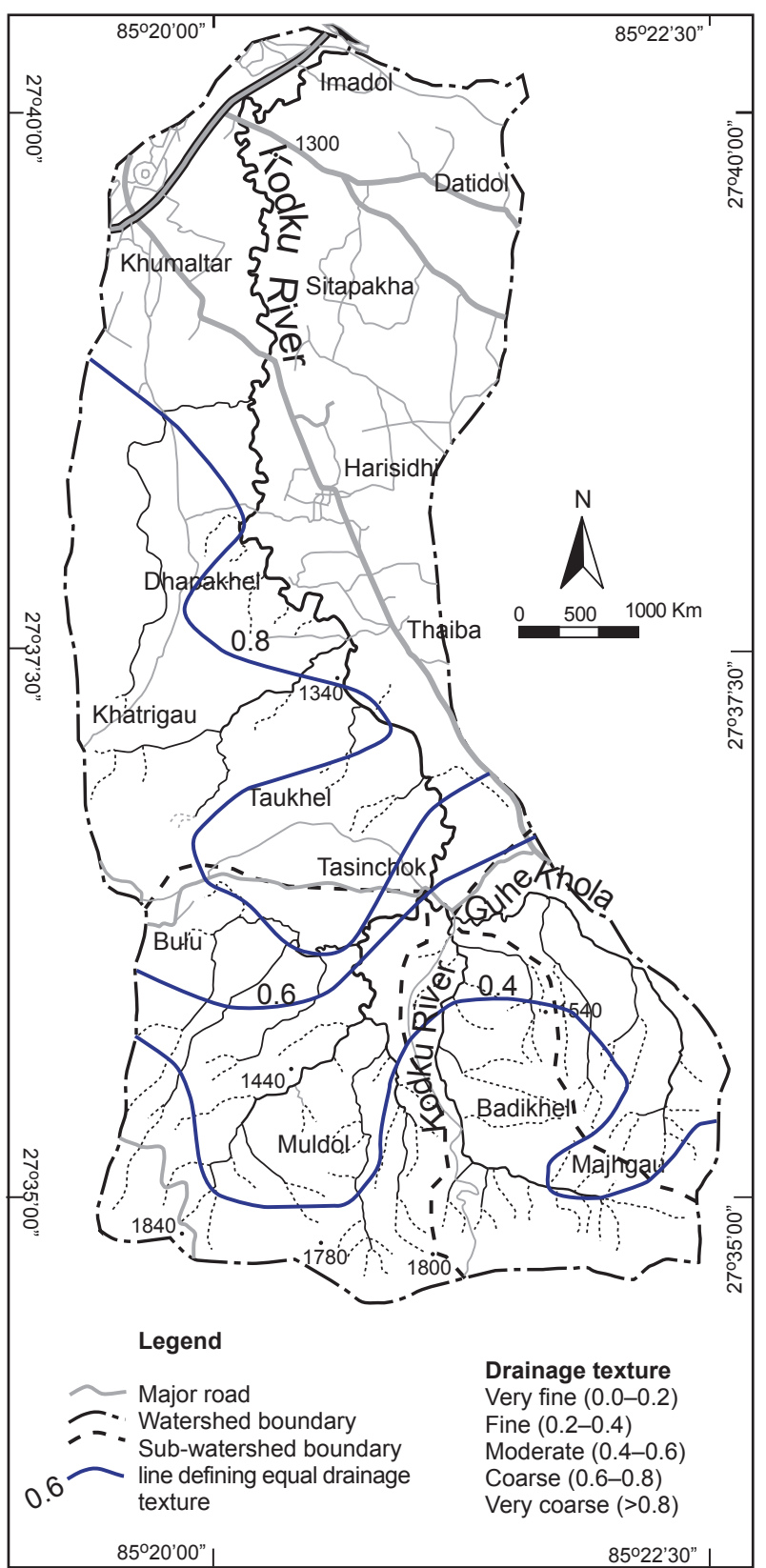

Fig. 3 A map showing drainage texture in the Kodkhu watershed.

stream stretches for about $3427.2 \mathrm{~m}$ from Majhgau up to the confluence of the Kodku River with the Guhe Khola (Figs. 4 and 5; Table 1). The fourth order main stem river stretches for $446.25 \mathrm{~m}$ up to Tasinchok where it confluences with the major tributaries extending from the Muldol sub-watershed. The fifth order main stem river stretches for about $11,995.2 \mathrm{~m}$ and finally contributes the Manahara River. 


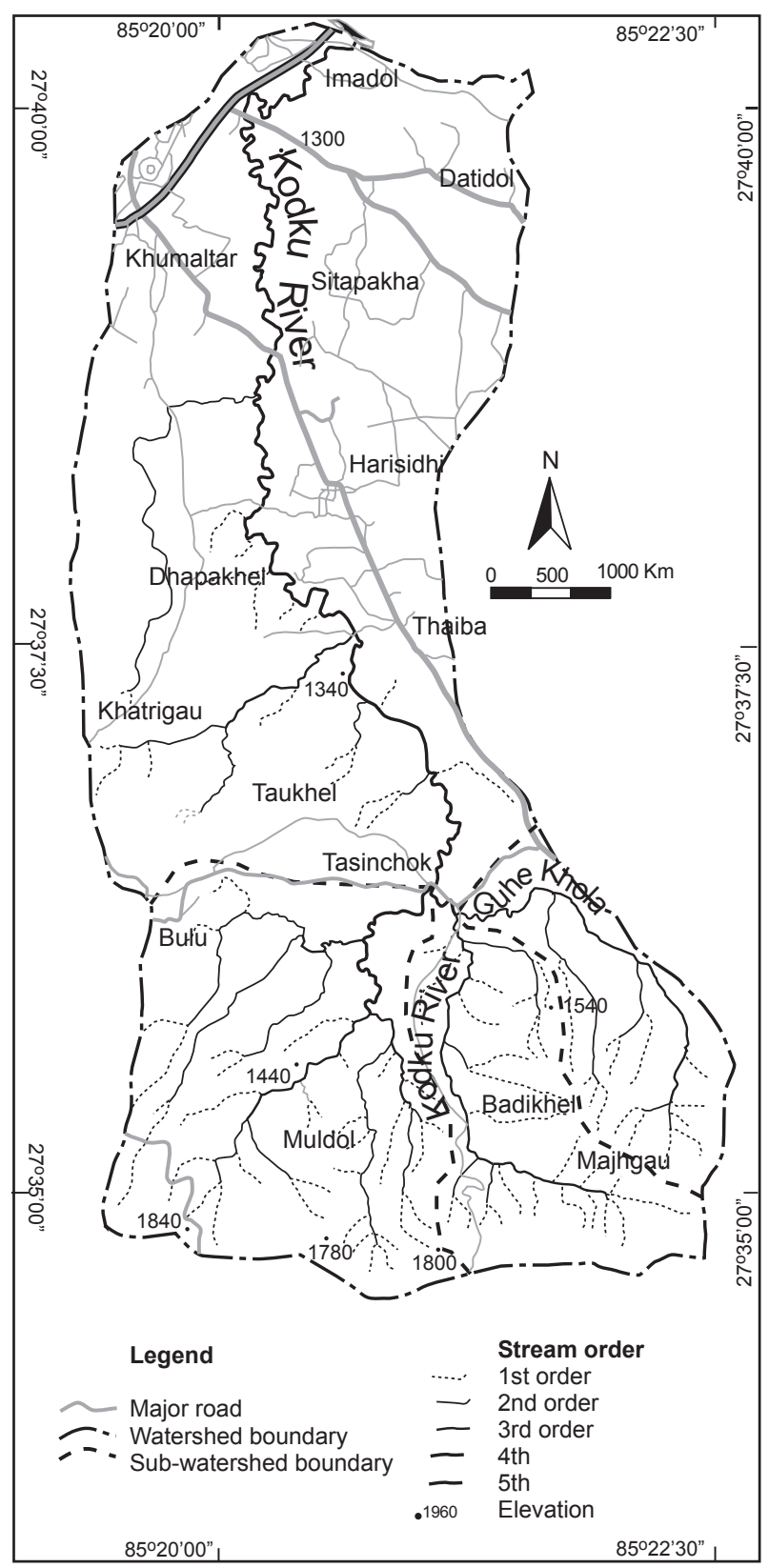

Fig. 4 A map showing stream order in the Kodkhu watershed.

\section{PLANFORM PARAMETRES OF THE KODKU RIVER}

\section{Sinuosity, meander belt width, meander wavelength and radius of curvature}

The planform geometry is well attributed by various parameters: sinuosity, meander wavelength, meander belt width, and radius of curvature. Sinuosity (K) is the ratio of stream channel length to down-valley distance.

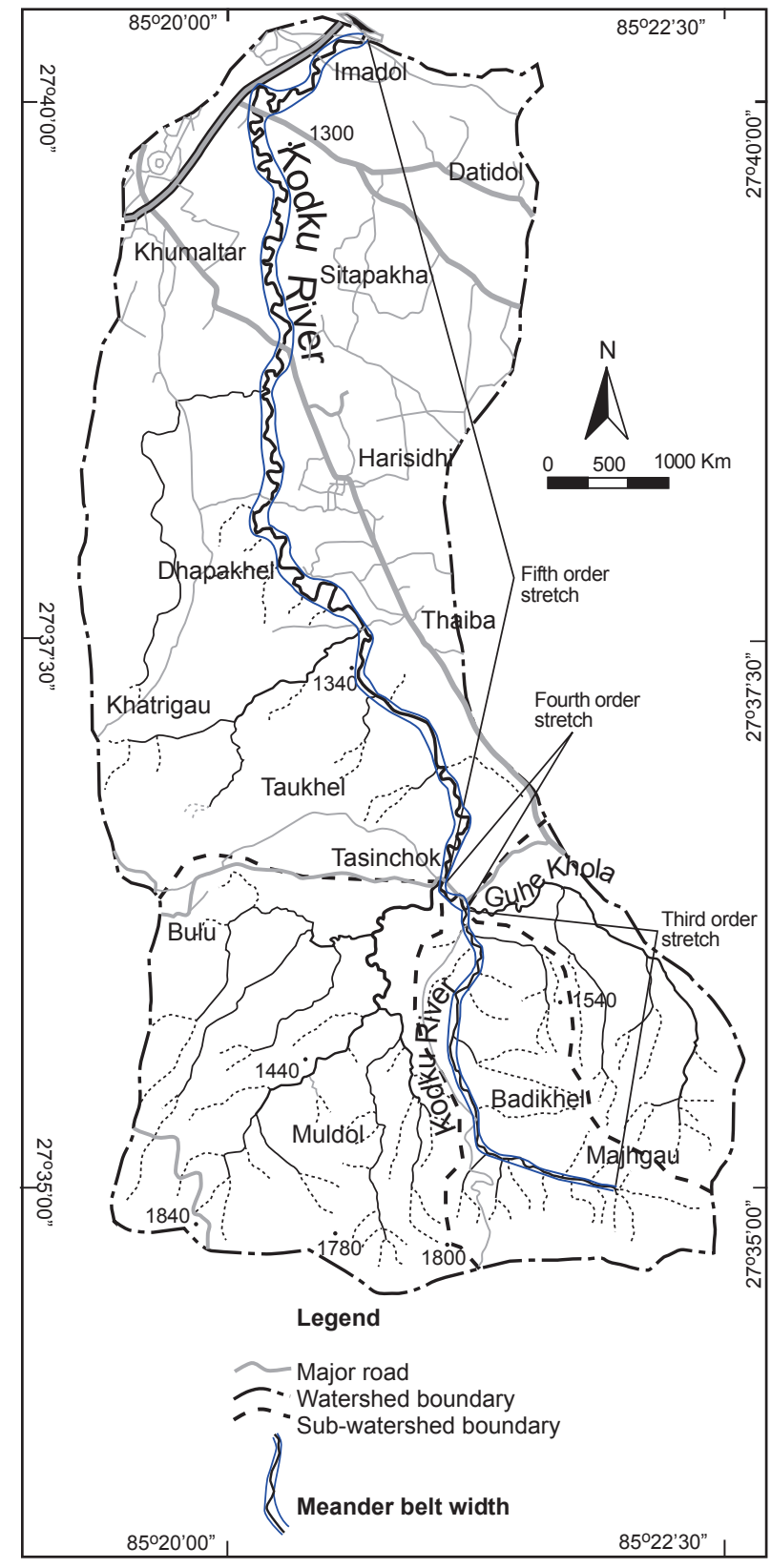

Fig. 5 A map showing stream stretches and a meander belt of the Kodkhu River.

Meander wavelength $\left(\mathrm{L}_{\mathrm{m}}\right)$ of the river is the distance between two successive crests or two successive trough of the curved channel. Meander belt width $\left(\mathrm{W}_{\mathrm{blt}}\right)$ is a straight line between the crest of the bend to the crest of the next bend lying downstream, or is the distance between lines defining the confinement of the lateral boundaries of the channel.

Radius of curvature $\left(R_{c}\right)$ is the radius of a circle drown through the apex of the bend and the two 


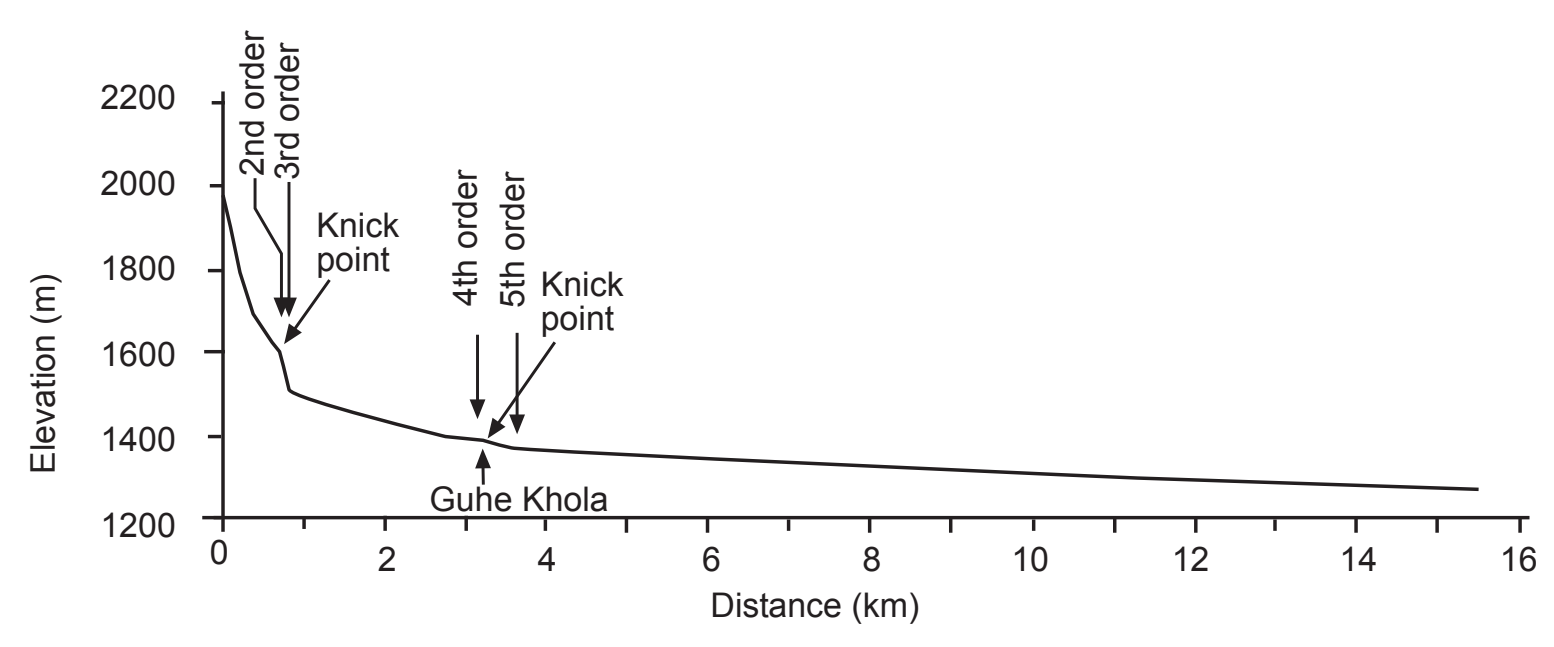

Fig. 6 A Longitudinal profile of the Kodku River.

crossover midpoint of river, and is defined as the curved surface formed by the meandering stream channel. All these parameters were calculated from the topographic map enlarge to $1: 10,000$-scale.

The result of planform parameters are listed in Table 1. Sinuosity indices of the third, fourth and fifth order main stem stretches of the Kodku River are 1.01, 1.32, and 1.33, respectively showing sinuous nature according to classification of Leopold and Wolman (1957). The Meander belt width $\left(\mathrm{W}_{\mathrm{blt}}\right)$ of the fifth order main stem river is $125.97 \mathrm{~m}$, while meander wavelength $\left(\mathrm{L}_{\mathrm{m}}\right)$, and Radius of curvature $\left(\mathrm{R}_{\mathrm{c}}\right)$ are respectively, $248.80 \mathrm{~m}$ and $65.56 \mathrm{~m}$. Both Wblt and $\mathrm{lm}$ diminish from the 3rd to the 4th order stretches, and increases drastically in the 5 th order stretch. Rc however remains almost similar.

\section{LONGITUDINAL PROFILE OF THE KODKU RIVER}

The longitudinal profile of the Kodku River reflects its gradient throughout its length (Fig. 6). The slopes of the 5 th, 4 th and 3 rd order stretches are $0.46 \mathrm{~m} / \mathrm{m}$, $1.31 \mathrm{~m} / \mathrm{m}$ and $3.58 \mathrm{~m} / \mathrm{m}$, respectively. The average slope of the Kodku River is $2.58 \mathrm{~m} / \mathrm{m}$. Two distinct knick points, one close to the emergence of the 3rd order and another close to the emergence of the 4th order streams, are present. The 3rd and 4th order main stem Kodku River stretches have tendency to erode their channel.

\section{WATERSHED-SCALE PARAMETERS OF THE GODAVARI RIVER}

\section{Relative relief}

The southern half of the Godavari watershed has extremely high relief (Fig. 7). The RR gradually decreases towards NW. High RR is found in Godavari, from where RR diminishes through moderate to low in Taukhel and Lubhu, and becomes extremely low in Ikudol where the Godavari River confluences with the Hanumante River. Mountain slope with bedrocks show high RR whereas soft valley fill sediments represent low to extremely low RR.

\section{Drainage texture}

DT of the Godavari Watershed ranges from fine to very coarse (Fig. 8). It is fine in the central region of the watershed including Godavari, and becomes coarse to very coarse in both northwestward and southeastward regions. DT in extremely coarse in Lubhu and Godavari Bhanjyang (ridge) areas, and is moderate in Ikudol, Ghimiregau and Kotdanda areas (Fig. 8).

\section{Stream order}

The Godavari Watershed comprises four subwatersheds; the Godavari sub-watershed, the Chisapani sub-watershed, Lubhu sub-watershed and the Charkhande sub-watershed. The latter three subwatersheds contribute laterally from the east to the 


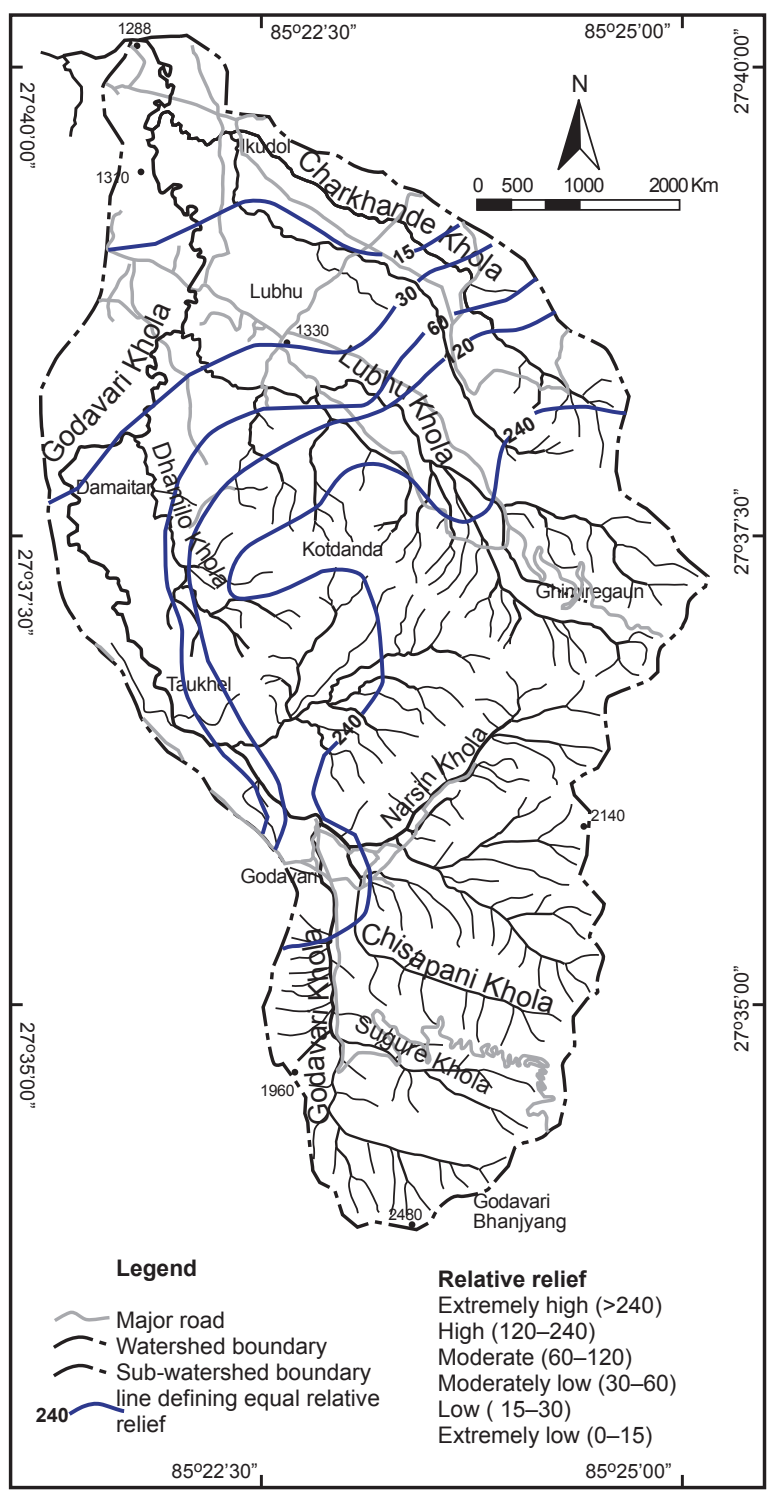

Fig. 7 A map showing relative relief in the Godavari watershed.

elongate Godavari Watershed. The Godavari main stem River is a fifth order river. There are altogether fourty 2nd order, fourteen 3rd order and four 4th order streams in the watershed. The third order stream stretches for about $1511.71 \mathrm{~m}$ from the Godavari Bhanjyang up to the confluence with the third order tributary coming from the eastern hill (Figs. 9 and 10; Table 1). The fourth order main stem river stretches for $2266.42 \mathrm{~m}$ up to Godavari where it confluences with the Chisapani Khola from the eastern hill. The fifth order main stem river stretches for about $113280.4 \mathrm{~m}$ and finally contributes the Hanumante River.

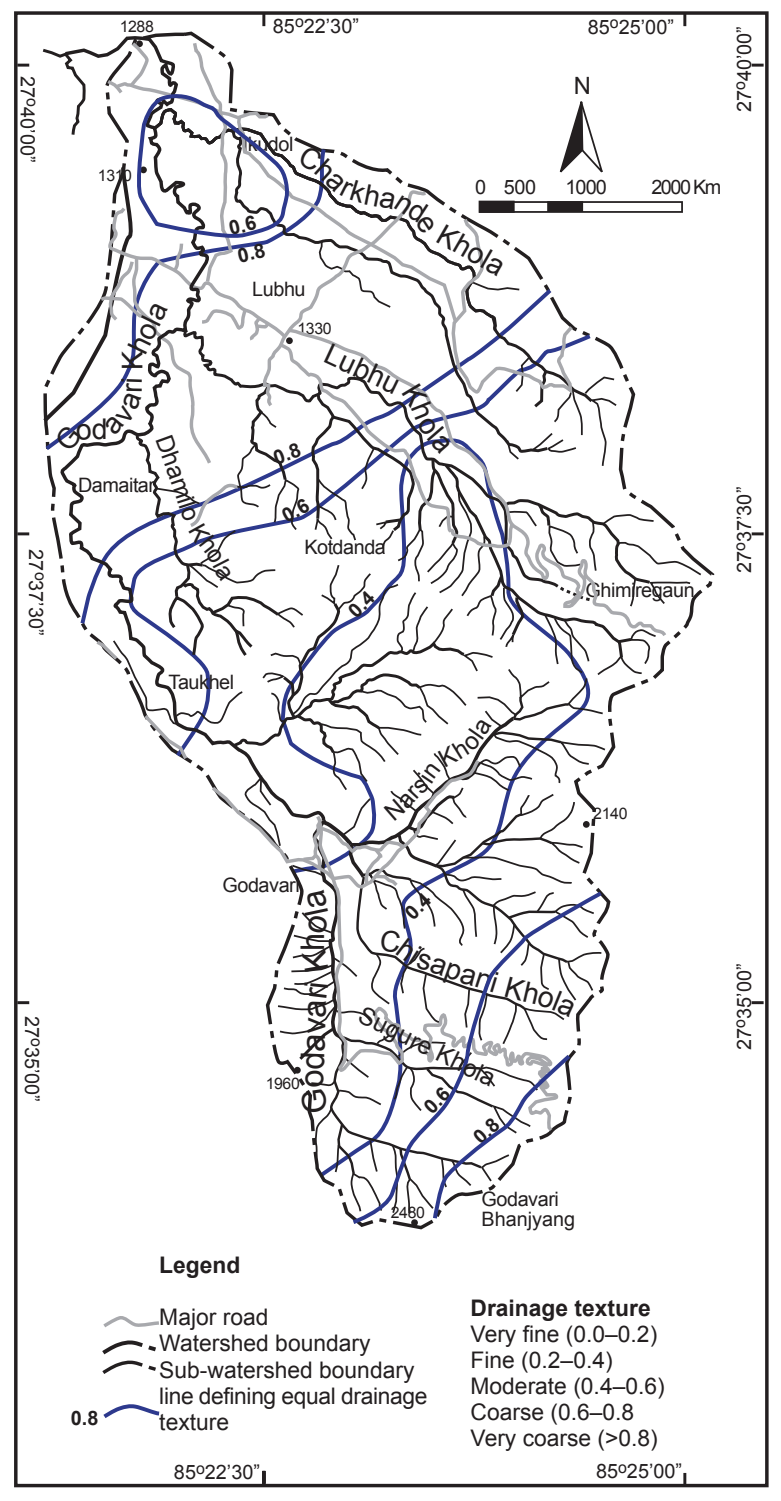

Fig. 8 A map showing drainage texture in the Godavari watershed.

\section{PLANFORM PARAMETRES OF THE GODAVARI RIVER}

\section{Sinuosity, meander belt width, meander wavelength and radius of curvature}

Sinuosity indices of the third, fourth and fifth order main stem stretches of the Godavari River are 1.05, 1.38 , and 1.62 , respectively showing sinuous nature of the 3 rd and 4th order stretches, while meandering pattern of the 5th order main stem Godavari River, according 


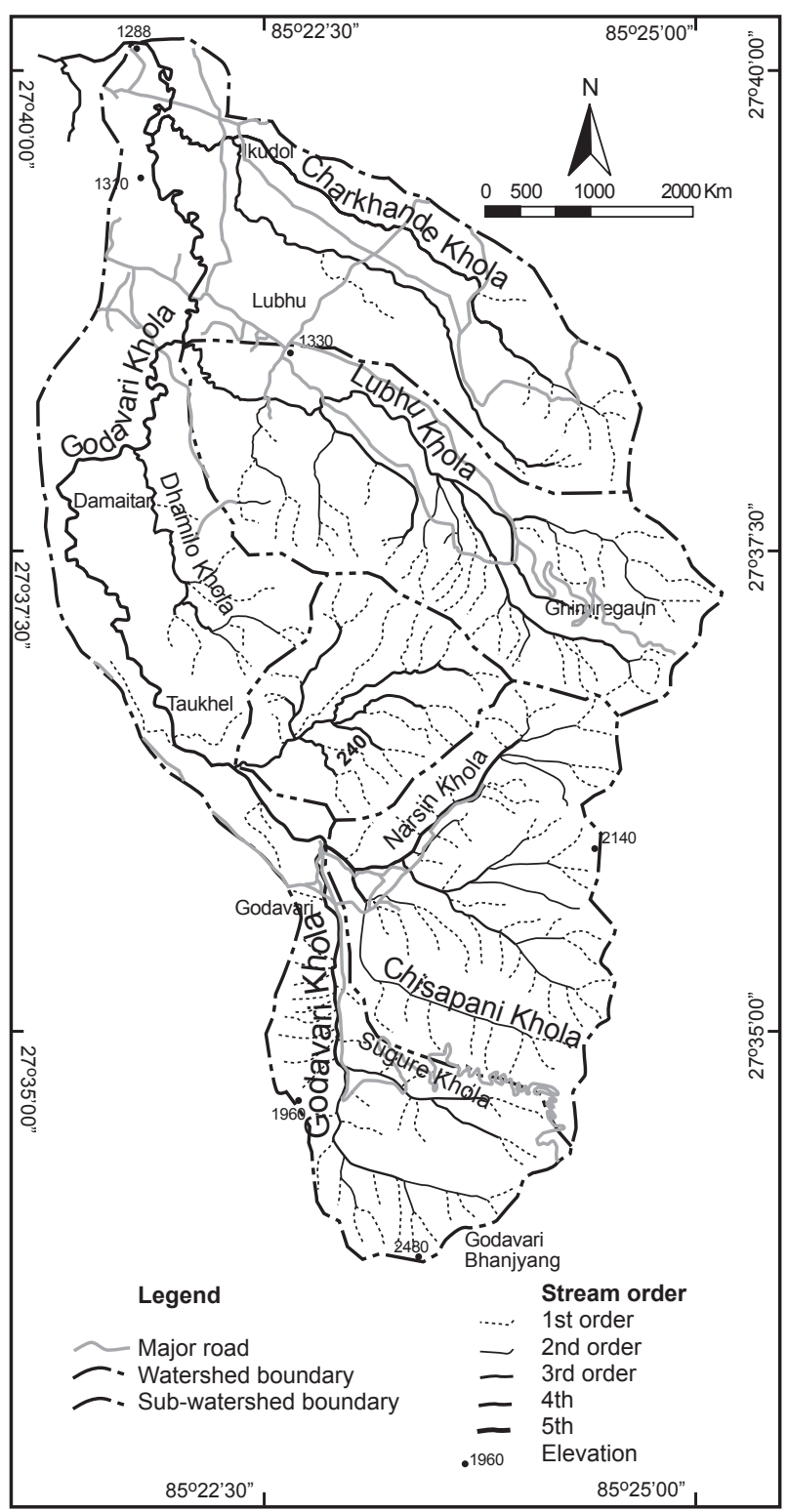

Fig. 9 A map showing stream order in the Godavari watershed.

to classification of Leopold and Wolman (1957). The Meander belt width (Wblt) of the fifth order main stem river is $138.92 \mathrm{~m}$, while meander wavelength $\left(\mathrm{L}_{\mathrm{m}}\right)$, and Radius of curvature $\left(\mathrm{R}_{\mathrm{c}}\right)$ are respectively, $301.80 \mathrm{~m}$ and $90.15 \mathrm{~m}$. W $\mathrm{Wlt}_{\mathrm{blt}}$ of the 5 th order stretch is almost three times that of the 4 th order stream. $\mathrm{L}_{\mathrm{m}}$ gradually increases from the $3 \mathrm{rd}$ order to the 5 th order stretch. $\mathrm{R}_{\mathrm{c}}$ however diminishes from the 4 th to the 5 th order stretch.

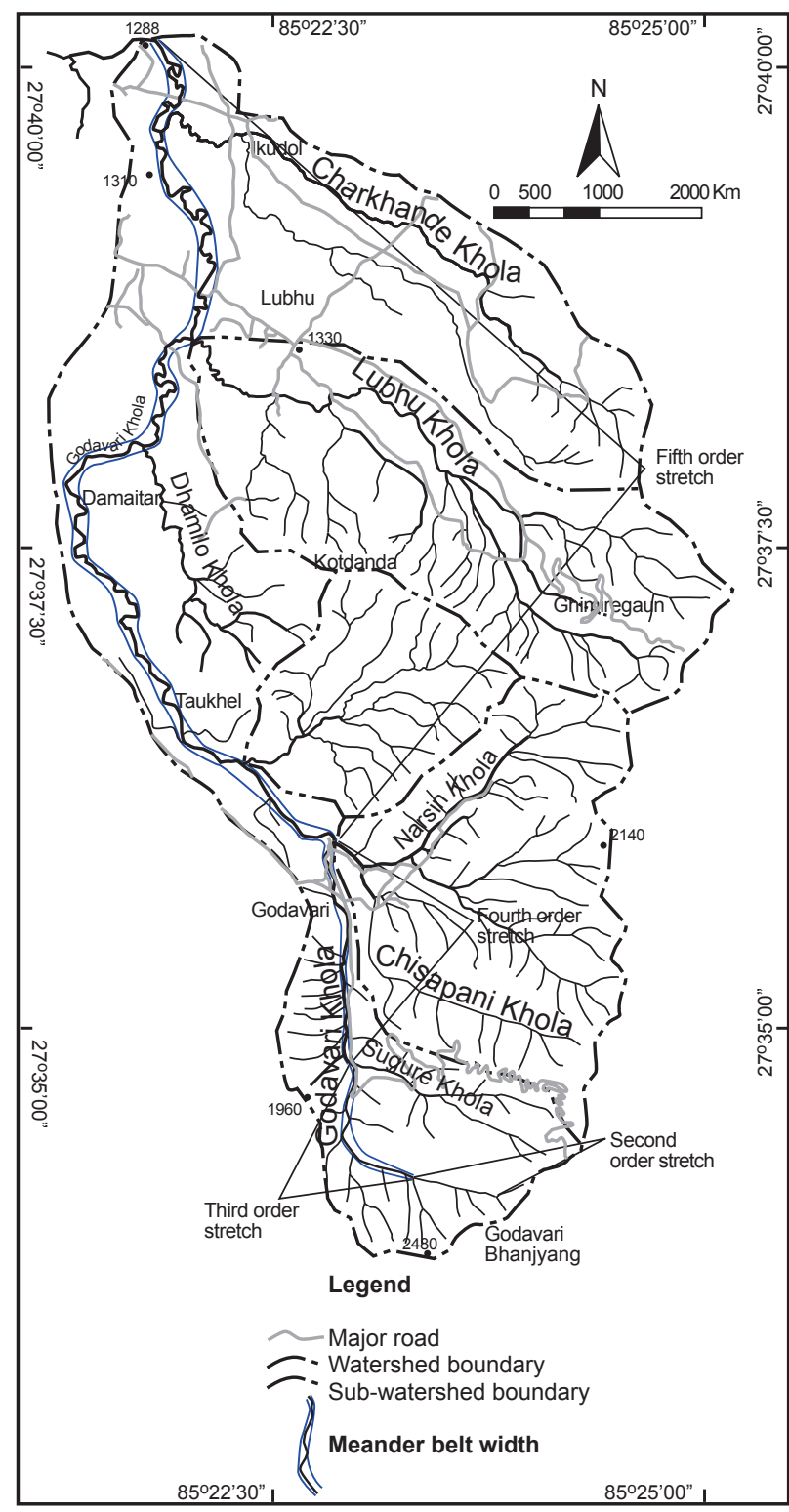

Fig. 10 A map showing stream stretches and a meander belt of the Godavari River.

\section{LONGITUDIANAL PROFILE OF THE GODAVARI RIVER}

The longitudinal profile of the Godavari River shows concave type of slope (Fig. 11). The slopes of the 5th, 4th and 3rd order stretches are $0.83 \mathrm{~m} / \mathrm{m}, 5.16 \mathrm{~m} / \mathrm{m}$ and $13.60 \mathrm{~m} / \mathrm{m}$, respectively. The average slope of the Godavari River is $4.18 \mathrm{~m} / \mathrm{m}$. The slope angles of all the stretches of the Godavari River are quite larger compared to those of the Kodku River. 


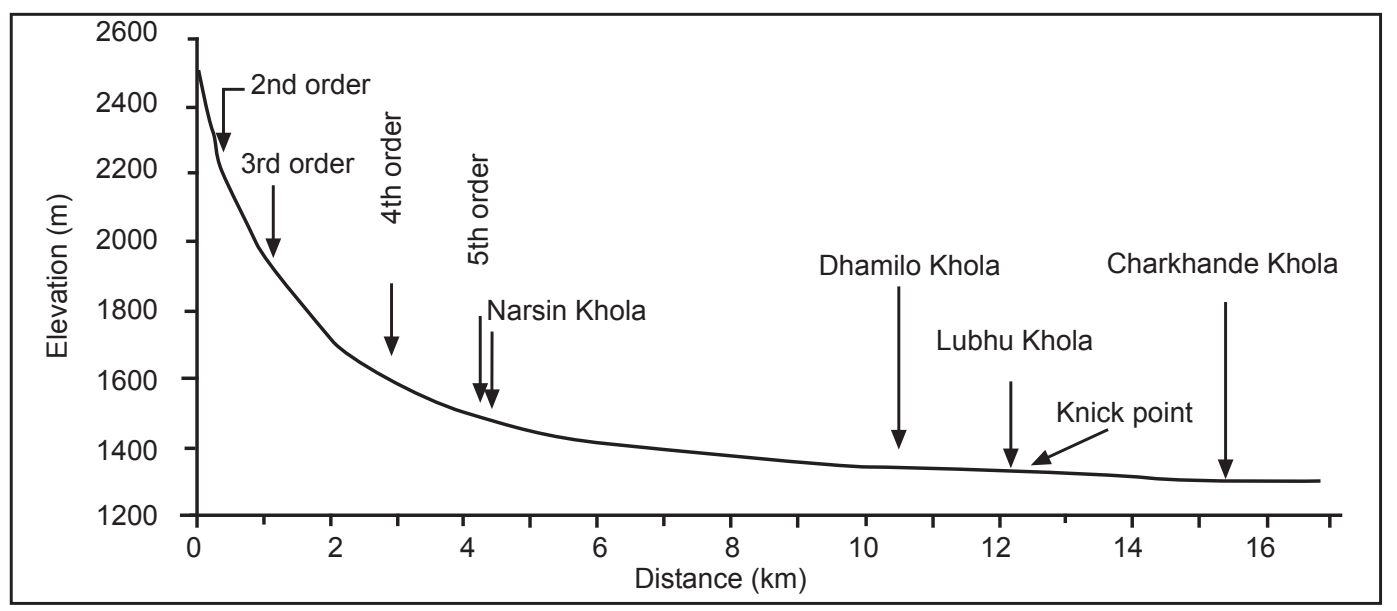

Fig. 11 A Longitudinal profile of the Godavari River.

\section{DISCUSSION AND CONCLUSION}

The Kodku and the Godavari Watersheds are elongate and the former is contributed by two sub-watersheds, and the latter by laterally the three sub-watersheds from the east. The Godavari River is longer and more sinuous than the Kodku River. In both rivers drainage texture is fine to very coarse and relative relief is extremely high to low or extremely low, showing very contrasting ranges of parameters, which are perhaps owing to the spatial variation of distribution of topographic highs and differences in stiffness in lithology.

The Kodku River falls under the sinuous river category whereas the Godavari River falls under the meandering river category. Considering the slopes of the fifth order streams the sinuosity of these rivers show anomalous patterns because more sinuous stream of the Godavari River has been developed in the slope which is two times that of the Kodku River.

In terms of meander belt width, meander wavelength and radius of curvature, the Godavari River is larger compared to the Kodku River. In both rivers, the planform parameters increase drastically when rivers emerge out as the fifth order main stem. Considering the meander loops of both rivers, they show in most of the cases asymmetrical patterns, indicating frequent retardation and dilation. This is presumably due to disturbances (effects of pulses arising from flash flooding, or any other natural and anthropogenic disturbances) to the rivers.

\section{REFERENCES}

Horton, R.E., 1945. Erosional development of streams and the streams and their drainage basins: Hydrological approach to quantitative geomorphology. Bulletin of the Geological Society of America, Vol. 56, pp. 275-370. h t t p : / / d x . d o i .org / $10.1130 / 0016$ 7606(1945)56[275:EDOSAT]2.0.CO;2

Leopold, L.B. and M.G. Wolman, 1957. River channel pattern-braided, meandering and straight, USGS Professional Paper 282B.

Leopold, L.B., Wolman, M.G. and Miller, J.P., 1964. Fluvial processes in Geomorphology, W.H. Freeman, San fransisco.

Shrestha, P. and Tamrakar, N.K., 2007. Streambank erodibility and lateral instability hazard in the Manahara River, Kathmandu Bsin, Nepal. Journ. Nepal Geol. Soc., v. 35, pp. 55-66.

Shrestha, P. and Tamrakar, N.K., 2011.Effects of human disturbances and climate on morphological changes of Bagmati River, central Nepal. Jour. Nepal. Geol. Soc., Special Issue, v. 43, pp. 205-218.

Singh, S., 1981. Estimation of drainage density, National Geographer, Vol. 16. No. 2, pp. 81-89.

Stöcklin, J., 1980. Geology of Nepal and its regional frame. Jour. Geol. Soc. London, v. 137, pp. 1-34. http://dx.doi.org/10.1144/gsjgs.137.1.0001

Strahler, A.N., 1957. Quantitative analysis of watershed geometry. Trans-American Geophysical Union, v. 38, pp. 913-920.

http://dx.doi.org/10.1029/TR038i006p00913

Strahler, A.N., 1969. Physical Geography. 3rd edition, John Willey and Sons, Inc. New York.

Tamrakar, N.K., 2004. Disturbances and instabilities in the Bishnumati River corridor, Kathmandu basin, JUSAN, v.9, pp. Issue 16, pp. 7-18. 